Article history: Submitted 25 December 2020; Accepted 18 January 2021; Available online 1 February 2021.

\title{
Persekusi Dalam Perspektif Hukum Positif Indonesia
}

\author{
Muhammad Hilman Anfasa Maaroef \\ anfasa66@gmail.com \\ Universitas Airlangga
}

Keywords:
Criminal Acts
of Persecution;
Criminal Liability;
Persecution

\begin{abstract}
This article is titled "Persecution in Criminal Law Perspective in Indonesia". The writing of this thesis refers to the normative juridical research method by using a legal and conceptual approach that is associated with several national laws such as, Law Number 1 of 1946 concerning Criminal Law Regulations, Law Number 26 of 2000 concerning Human Rights Court, Law Number 40 Year 2008 concerning the Elimination of Discrimination and Race, and Law Number 5 Year 2018 concerning Eradication of Criminal Terrorism. This study aims to determine the actions that are qualified as persecution in criminal law and criminal liability against perpetrators of persecution. This research shows that persecution is a criminal offense by fulfilling elements of general criminal rules and special crimes related to the qualification of criminal acts. In Indonesia, criminal liability for perpetrators there is still no specific regulation governing the imposition of criminal sanctions, so that liability is contained in separate regulations which cause overlapping of each of the regulations. Every legislation related to the persecution has different differences, such as the form of actions and motives for their actions. Based on this research, the government as a protector and guarantor of the rights of its citizens needs to specifically regulate persecution for the sake of legal certainty in a country.
\end{abstract}

\begin{abstract}
Kata Kunci:
\section{Abstrak}

Tindak Pidana Artikel ini berjudul "Persekusi dalam Perspektif Hukum Positif Indonesia". Persekusi; Per- Penulisan skripsi ini mengacu pada metode penelitian yang bersifat yuridis tanggungjawaban normatif dengan menggunakan pendekatan undang-undang dan pendekatan Pidana; Persekusi. konseptual yang dikaitkan dengan beberapa undang-undang nasional seperti, Undang-Undang Nomor 1 Tahun 1946 tentang Peraturan Hukum Pidana, UndangUndang Nomor 26 Tahun 2000 tentang Pengadilan Hak Asasi Manusia, UndangUndang Nomor 40 Tahun 2008 tentang Penghapusan Diskriminasi dan Ras, dan Undang-Undang Nomor 5 Tahun 2018 tentang Pemberntasan Pidana Terorisme. Penelitian ini bertujuan untuk mengetahui perbuatan yang dikualifikasi sebagai persekusi dalam hukum pidana serta pertanggungjawaban pidana terhadap pelaku persekusi. Penelitian ini menunjukkan bahwa persekusi merupakan tindak pidana dengan memenuhi unsur-unsur peraturan pidana umum dan pidana khusus terkait kualifikasi tindak pidananya. Di Indonesia pertanggungjawaban pidana bagi pelaku masih belum ada peraturan secara khusus yang mengatur mengenai pemberian sanksi pidana, sehingga pertanggungjawabannya terdapat dalam peraturan yang terpisah yang menyebabkan tumpeng tindih terhadap masing-masing peraturannya. Setiap perundang-undangan yang terkait dangan persekusi memiliki perbedaan masing-masing seperti bentuk perbuatan dan motif perbuatannya. Berdasarkan penelitian ini, pemerintah sebagai pelindung dan penjamin hak warga negaranya perlu mengatur secara khusus terkait persekusi demi kepastian hukum dalam suatu negara.
\end{abstract}


Muhammad Hilman: Persekusi Dalam Perspektif...

\section{Pendahuluan}

Demi mewujudkan penegakan hukum di Indonesia diperlukan suatu produk hukum yang dalam hal ini adalah undang-undang, yang mempunyai fungsi sebagai pengatur tindakan masyarakat serta sebagai pedoman kepada masyarakat agar terciptanya suatu tatanan hidup masyarakat yang tertib dan teratur, sehingga apabila ada pihak yang melanggar aturan yang berlaku dapat dikenakan hukuman. Hal ini sesuai dengan sendi utama negara yang berdasarkan hukum sebagai sumber tertinggi dalam mengatur hubungan hukum antara negara dan masyarakat maupun antara anggota atau kelompok masyarakat yang satu dengan lainnya. Akhir-akhir ini, di Indonesia banyak diberitakan kasus- kasus kejadian persekusi. Southeast Asia Freedom of Expression Network (SAFEnet) mendata ada sekitar 59 kasus persekusi yang terjadi di Indonesia sejak 27 Januari - akhir Mei 2017 ini,korban umumnya dinilai menghina tokoh dari ormas. ${ }^{1}$ Persekusi ini merupakan salah satu jenis kejahatan kemanusiaan sebagaimana dijelaskan dalam Statuta Roma, Pasal 7 ayat (1), yaitu " Crime against humaniy means any of the following acts when commited as part of widespread or systematic attack directed against any civilian population, with knowledge of attack". Pasal 7 ayat (2) huruf g, "Persecution means the intentional and severe deprivation of fundamental rights contrary to international law by reason of the identity of the group or collectivity;".

Ketentuan pasal tersebut menjelaskan bahwa "persecution" berarti perampasan secara sengaja dan kejam terhadap hak-hak dasar yang bertentangan dengan hukum internasional dengan alasan politik, ras, nasional, etnis, budaya, agama, gender. Berdasarkan Kamus Besar Bahasa Indonesia (KBBI) maka arti kata dari persekusi ini adalah pemburuan sewenang-wenang terhadap seorang atau sejumlah warga dan disakiti, dipersulit, atau ditumpas. ${ }^{2}$ Namun apabila kata persekusi dijadikan sebagai kata kerja yaitu "memperkusi" memiliki arti menyiksa, atau menganiaya ${ }^{3}$ sehingga ada unsur praktik adanya suatu penyiksaan.

1 Dyah Naelufar 'Indonesia Melawan Bahaya Persekusi' (Liputan 6 news 2017) https://www. liputan6.com/news/read/2982511/indonesia-melawan-bahaya-persekusi diakses pada 20 Agustus 2019.

2 kbbi.web.id/persekusi diakses pada 20 agustus 2019 pukul 9.30 WIB.

3 ibid. 
Persekusi dilakukan tanpa dasar kewenangan yang diatur undang-undang. Hal ini akan dapat mengancam seseorang dalam berdemokrasi dan mengekspresikan suatu pendapat yang dijamin undang-undang dan dapat berakibat meresahkan publik. Atas kejadian kasus-kasus persekusi, seharusnya pihak yang berwenang yaitu Aparat Penegak Hukum yang selanjutnya disingkat APH bertindak aktif untuk menyelesaikan sesuai ketentuan. Hal ini untuk mencegah dan membuat tidak terulangnya kembali kejadian persekusi dikemudian hari dan menutup peluang terjadinya upaya balasan dari korban pada waktu dan di tempat lain kepada persekutor. Persekusi ini ada dikarenakan banyaknya keinginan untuk memaksakan suatu kehendaknya agar diterima oleh orang lain melalui prosesproses yang secara hukum tidak diperbolehkan karena dalam perbuatannya merugikan pihak lain, namun pelaku memaksakannya dengan bentuk perbuatan yang berkaitan dengan kekerasan. Persekusi ini juga disebabkan karena adanya kefanatikan ide terhadap kepercayaan dari pandangan diri seseorang atau kelompok yang menyebabkan gejolak antara kedua pihak yang tidak sependapat pemikirannya yang kemudian menimbulkan perbuatan-perbuatan yang dilarang menurut hukum, ${ }^{4}$ Sistem hukum di Indonesia hingga sampai saat ini masih belum ada ketentuan-ketentuan atau undang-undang yang menjelaskan tentang bentuk-bentuk dan aturan yang mengatur tentang persekusi ini. Hal ini yang dapat menjadi isu hukum bahwa, apakah bisa persekusi ini dikaitkan dengan ketentuan-ketentuan atau undang-undang yang berlaku di Indonesia agar tindakan persekusi ini tidak menimbulkan dampak kerugian bagi seseorang atau kelompok yang merasa dipersekusi oleh persekutor dan pelaku mendapat sanksi hukum yang tegas atas perilaku yang membuat resah masyarakat, Dengan adanya aturan yang jelas mengenai sanksi yang akan diterapkan kepada pelaku persekusi maka akan mengurangi jumlah kasus persekusi yang ada di Indonesia dan dapat mengantisipasi apabila terjadi kasus yang berkaitan dengan persekusi.

4 Caecilia Fika, 'Melawan Persekusi Atas Kebebasan Berpendapat' ( Kompasiana, 2017) https://www.kompasiana.com/caeciliafica/593bccffbc22bd204122edac/melawan-persekusi-atas-kebebasanberpendapat diakses pada 20 Agustus 2019. 
Muhammad Hilman: Persekusi Dalam Perspektif...

Maka adanya aturan yang jelas membuat masyarakat yakin akan perlindungan hukum kaitannya dengan persekusi.

\section{Perbuatan yang Dikualifikasi Sebagai Persekusi Dalam Hukum Pidana}

Menurut strata roma persekusi pada awalnya digolongkan kedalamkejahatan kemanusiaan yaitu Persecution yang merupakan salah satu kejahatan kemanusiaan yang diatur dalam statute roma memilikin arti yang dijelaskan dalam Pasal 7 ayat (2) huruf g, "Persecution means the intentional and severe deprivation of fundamental rights contrary to international law by reason of the identity of the group or collectivity;" kaitannya dengan ketentuan ini ada unsur kesengajaan melakukan perampasan terhadap hak-hak fundamental yang bertentangan dengan hukum internasional dengan identitas kelompok. Melakukan perampasan hak-hak fundamental seperti pembunuhan, pemusnahan, pemindahan paksa penduduk, kejahatan apartheid, penyiksaan, penghilangan paksa. Identifiable group atau kelompok yang memiliki karakteristik tertentu. Berdasarkan ketentuan statute roma ditunjukkan bahwa bentuk perbuatan melawan hukum yang diuraikan dalam ketentuan Pasal 7 ayat (1) seperti: pembunuhan, pemusnahan, pemindahan paksa penduduk, kejahatan apartheid, penyiksaan, penghilangan paksa, pemerkosaan dengan motif politik, ras, kebangsaan, etnis, budaya, agama dan jenis kelamin.

Definisi persekusi sendiri apabila dilihat dalam Black's Law Dictionary diartikan sebagai "Persecution means Violent, cruel, and oppressive treatment directed toward a person or group of persons because of their race, religion, sexual orientation, politics, or other beliefs". ${ }^{5}$ Yang apa bila diterjemahkan, Penganiayaan berarti perlakuan yang kejam, dan menindas yang ditujukan kepada seseorang atau sekelompok orang karena ras, agama, orientasi seksual, politik, atau kepercayaan lain. Konsep persekusi yang dijelaskan dalam statuta roma dapat dikaitkan kedalam undang-undang nasional seperti : KUHP, Undang-Undang Pengadilan HAM, Undang-Undang Pemberantasan Tindak Pidana Terorisme, Undang-Undang Penghapusan Diskriminasi Ras dan Etnis.

5 Hendry Campbell Black, "Black's Law Dictionary Centennial Sixth Edition" (St. Paul, Minn: West Publishing co. 1990).[64]. 
Berdasarkan KUHP pasal 170, 353, 340, 285 yang berkaitan dengan bentuk perbuatan persekusi. Pasal 170 KUHP dapat dikaitkan dalam konsep persekusi statute roma yang menjelaskan bahwa adanya tindakan diskriminasi menggunakan kekerasan yang menyebabkan luka terhadap orang lain dengan maksud untuk menghukum atau meniadakan kelompok yang bersebrangan pendangan oleh pelaku persekusi dan bentuk tindakannya dapat ditakitkan dengan pasal ini karena menggunakan kekerasan dalam tindakannya dan dilakukan secara bersama-sama karena yang dimaksud kelompok lebih dari satu orang. ${ }^{6}$ Pasal 353 KUHP dapat dikaitkan dengan tindak pidana persekusi yang dikualifikasikan sebagai delik penganiayaan dengan rencana karena apabila dikaitkan dengan konsep dalam statute roma bentuk perbuatannya mekalukan penganiayaan terhadap korbannya yang dilakukan secara berkelompok dan menimbulkan kerugian yang dialami korbannya. ${ }^{7}$ Pasal 340 KUHP tindak pidana persekusi dapat dikualifikasikan sebagai delik pembunuhan dengan rencana karena apabila dikaitkan dengan konsep statute roma bentuk perbuatannya mekalukan pembunuhan terhadap korbannya dan menimbulkan hilangnya nyawa korbannya. ${ }^{8}$ Pasal 285 KUHP tindak pidana persekusi dapat dikualifikasikan sebagai delik pemerkosaan karena dalam bentuk perbuatannya mekalukan perbudakan seksual terhadap korbannya sesuai dengan konsep yang dijelaskan dalam statuta roma. ${ }^{9}$

Berdasarkan Undang-Undang Pengadilan HAM persekusi dikaitkan dengan ketentuan Pasal 9 huruf h karena bentuk perbuatannya adalah penganiayaan dan diikuti oleh motif yang berkaitan dengan persekusi yang dijelaskan dalam statute roma yaitu, politik, ras, kebangsaan, etnis, budaya, agama, jenis kelamin. Maka pasal ini juga memiliki kaitan dengan konsep statuta roma karena bentuk tindakan dan motif yang melatar belakangi perbuatannya.

\footnotetext{
6 P.A.F. Lamintang dan C.D. Samosir, Hukum Pidana Indonesia (Sinar Baru 1983).[82].

7 Lamintang, P.A.F dan Theo Lamintang, Kejahatan Terhadap Nyawa, Tubuh, \& Kesehatan (Sinar Grafika 2010).[132].

8 ibid.[155].

9 P.A.F Lamintang \& Theo Lamintang, Kejahatan Melannggar Norma Kesusilaan Norna Kepatutan (Sinar Grafika 2009).[55].
} 
Muhammad Hilman: Persekusi Dalam Perspektif...

Berdasarkan Undang-Undang Penghapusan Diskriminasi Ras dan Etnis persekusi dikaitkan dengan ketentuan Pasal 4 undang-undang ini karena ada tindakan diskriminasi yang berkaitan dengan motif etnis dan ras. Tindakan diskriminasi seperti menunjukkan kebencian atau rasa benci kepada orang karena perbedaan ras dan etnis, dan memperlakukan pembedaan, pengecualian, pembatasan, atau pemilihan berdasarkan pada ras dan etnis. Maka pasal ini juga memiliki kaitan dengan konsep statuta roma karena bentuk tindakan dan motif yang melatar belakangi perbuatannya.

Berdasarkan Undang-Undang Pemberantasan Tindak Pidana Terorisme persekusi dikaitkan dengan ketentuan Pasal 6 undang-undang ini karena unsur motif politik dan ideologi maka ketentuan pasal ini dapat dikaitkan karena berhubungan dengan motifnya, dan bentuk perbuatannya juga dapat dikaitkan dengan tindakan diskriminasi karena ada upaya untuk merampas kemerdekaan orang lain, menghilangkan nyawa orang lain dan mengakibatkan kerusakan terhadap fasilitas pubilk.

Dengan diuraikannya delik dalam tindak pidana persekusi yang dikaitkan dengan suatu delik yang ada dalam KUHP, Undang-Undang Pengadilan HAM, UndangUndang Penghapusan Diskriminasi Ras dan Etnis, Undang-Undang Pemberantasan Tindak Pidana Terorisme. Persekusi memiliki cakupan yang luas karena ada motif yang melandasi suatu perbuatannya, dan motif tersebut dalam ketentuan hukum nasional juga diatur dalam beberapa undang-undangnya yang membuat persekusi dapat dikualifikasikan kedalam beberapa undang-undang nasional.

\section{Pertanggungjawaban Pidana Pelaku Persekusi}

Hukum pidana juga dikenal dengan asas pertanggungjawaban "geen straf zonder schuld; actus non facit reum nisi mens sit rea" yang berarti bahwa seseorang tidak dapat dipidana jika tidak ada kesalahan. ${ }^{10}$ Pertanggungjawaban pidana terhadap pelaku dapat dijatuhkan selama pelaku telah melakukan suatu tindak pidana yang

${ }_{10}$ Moeljatno, Asas-Asas Hukum Pidana, (PT Rineka Cipta 2000).[163]. 
dalam ketentuan pidana telah diatur dan telah memenuhi beberapa unsur tindak pidana sebagaimana dijabarkan dalam ketentuan undang-undang yang berlaku. Mengenai pertanggungjawaban pidana, seorang pelaku tindak pidana harus terbukti melakukan kesalahan yang sifatnya melawan hukum.Tindakan persekusi yang masuk kedalam kualifikasi sebagai perbuatan yang diatur didalam KUHP dan dalam peruatannya dapat dipertanggungjawabkan yakni:

1. Pasal 170 KUHP tentang kejahatan ketertiban umum. Pasal ini dikhususkan terkait bentuk perbuatan persekusi yang dalam melakukan tindakan kekerasan yang dilakukan secara bersama-sama atas dasar motif tertentu. Dalam sudut pandang subjektif terdapat frasa "dengan sengaja" yang memiliki arti bahwa dalam suatu tindakannya dilakukan dengan niat sengaja untuk mekakukan tindakannya. Dilihat dari sudut pandang objektif bentuk perbuatan yang dilakukan secara bersama-sama yaitu dengan cara mengeroyok disertai dengan kekerasan. Jika menimbulkan kerugian akibat dari perbuatan tersebut seperti luka terhadap korbannya sesuai dengan ketentuan Pasal 170 ayat (2) angka 1 maka diancam dengan pidana penjara paling lama 7 tahun, jika menimbulkan luka berat terhadap korbannya sesuai ketentuan Pasal 170 ayat (2) angka 2 maka diancam dengan pidana penjara paling lama 9 tahun, jika menimbulkan kematian terhadap korbannya maka diancam pidana penjara paling lama 12 tahun. ${ }^{11}$

2. Pasal 353 KUHP tentang penganiayaan berencana, pasal ini digunakan karena bentuk perbuatan persekusi melakukan penganiayaan terhadap korbannya karena perbedaan motif tertentu, namun penerapannya dalam KUHP tidak perlu pembuktian lebih lanjut terkait motif. Dari sudut pandang subjektif dalam pasal ini dapat dilihat karena ada frasa "rencana" yang termasuk dalam niat pelaku untuk melakukan suatu perbuatan telah diatur sedemikian rupa hingga terlaksannya suatu perbuatan itu. Dari sudut pandang objektif dapat dilihat dari perbuatan penganiayaan tersebut, pelaku melakukan suatu

11 P.A.F. Lamintang dan C.D. Samosir, Op.Cit.[85]. 
Muhammad Hilman: Persekusi Dalam Perspektif...

perbuatan seperti memukul, melempari batu, menyabet dengan kayu. Jika menimbulkan kerugian terhadap korbannya karena perbuatan penganiayaan itu sesuai ketentuan Pasal 353 ayat (1) KUHP depat diancam pidana paling lama 4 tahun apabila melakukan penganiayaan berencana, jika mengakibatkan luka berat diancam pidana paling lama 7 tahun, jika mengakibatkan kematian diancam pidana paling lama 9 tahun. ${ }^{12}$

3. Pasal 340 KUHP tentang pembunuhan berencana kaitannya dengan bentuk perbuatan persekusi menghilangkan nyawa orang lain karena diskriminasi terhadap motif tertentu. Dari sudut panndang subjektif dapat mudah diketahui karena ada frasa "berencana" karena sebelum melakukan pembunuhan, pelaku telah berniat untuk melakukan suatu perbuatan itu karena sebelum perbuatan itu terjadi pelaku telah menetapkan tujuan dan mengetahui akibat dari perbuatan itu. Dari objektif dapat dilihat dari tindakan pelaku saat melakukan suatu perbuatan, seperti pelaku menusuk dengan pisau terhadap diri korban. karena perbuatannya menimbulkan suatu kerugian terhadap orang lain maka pelaku diancam dengan pidana mati atau pidana seumur hidup atau selama waktu tertentu paling lama 20 tahun. ${ }^{13}$

Pasal 285 KUHP tentang pemerkosaan kaitannya dengan bentuk perbuatan persekusi yang melakukan perbudakan seksual terhadap korbannya. Dari sudut pandang subjektif dapat dilihat dari adanya suatu ancaman yang dilakukan oleh pelaku karena dengan ancaman dapat dilihat bahwa adanya kehendak untuk mengancam seseorang agar melakukan perintah pelaku. Dari sudutpandang objektif dapat dilihat dari tindakan pelaku melakukan suatu perbuatan, hal ini dapat diketahui karena pelaku melakukan hubungan seksual terhadap korbannya disertai dengan kekerasan bisa berupa tindakan atau ancaman kekerasan. Karena perbuatannya ada pihak yang dirugikan maka pelaku diancam dengan pidana selama-lamanya 12 tahun. ${ }^{14}$ Ancaman kekerasan menurut Adami Chazawi

\footnotetext{
${ }^{12}$ Lamintang, P.A.F dan Theo Lamintang, Op.Cit.[141].

13 Andi Hamzah, Delik-Delik Tertentu didalam KUHP (Sinar Grafika 2017).[68].

14 P.A.F Lamintang \& Theo Lamintang,Op.Cit.[55].
} 
yaitu ancaman kekerasan fisik yang ditujukan pada orang, yang pada dasarnya juga berupa perbuatan fisik, dimana perbuatan fisik tersebut berupa perbuatan persiapan untuk dilakukan perbuatan fisik yang lebih besar yang berupa kekerasan yang akan mungkin segera dilakukan jika ancaman itu tidak membuahkan hasilseperti yang diinginkan pelaku. ${ }^{15}$

Berdasarkan Undang-Undang Pengadilan HAM, pelaku tindak pidana persekusi dalam perumusan ketentuan Pasal 9 huruf $\mathrm{h}$ Undang-Undang Pengadilan HAM karena dalam perbuatannya melakukan penganiayaan terhadap korbannnya dengan motif tertentu maka sanksi pidana apabila melanggar ketentuan Pasal 9 huruf h dikenai sanksi pidana sebagaimana yang telah diatur dalam Pasal 40 Undang-Undang Pengadilan HAM, yaitu: “Setiap orang yang melakukan perbuatan sebagaimana dimaksud dalam Pasal 9 huruf g,h,dan I dipidana dengan pidana penjara paling lama 20 (dua puluh) tahun dan paling singkat 10 (sepuluh) tahun“. Dengan demikian apabila unsur subjektif dan objektif serta motif dalam ketentuan Pasal 9 huruf h Undang-Undang Pengdilan HAM telah terpenuhi dan dibuktikan bahwa perbuatan yang dilakukan oleh pelaku terbukti melakukan kesalahan dan menimbulkan kerugian terhadap korban, maka akan dikenai sanksi pidana yang sebagaimana diatur dalam ketentuan Pasal 40 Undang-Undang Pengadilan HAM.

Berdasarkan Undang-Undang Penghapusan Diskriminasi Ras dan Etnis, larangan diskriminasi terhadap ras dan etnis, dalam Undang-Undang Nomor 40 Tahun 2008 tentang Penghapusan Diskriminasi Ras dan Etnis juga menyertakan sanksi yang diberikan kepada oknum yang melanggar ketentuan Pasal 4 UndangUndang Nomor 40 Tahun 2008 tentang Penghapusan Diskriminasi Ras dan Etnis. Dijelaskan dalam ketentuan pidana sebagai berikut:

Pasal 15

Setiap orang yang dengan sengaja melakukan pembedaan,menunjukkan kebencian pengecualian, pembatasan, atau pemilihan berdasarkan pada ras dan etnis yang mengakibatkan pencabutan atau pengurangan

${ }^{15}$ Adami Chaznawi, Tindak pidana Mengenai Kesopanan (Raja Grafindo 2007).[65]. 
Muhammad Hilman: Persekusi Dalam Perspektif...

pengakuan, perolehan atau pelaksanaan hak asasi manusia dan kebebasan dasar dalam suatu kesetaraan di bidang sipil, politik, ekonomi, sosial, dan budaya sebagaimana dimaksud dalam Pasal 4 huruf a, dipidana dengan pidana penjara paling lama 1 (satu) tahun dan/atau denda paling banyak Rp100.000.000,00 (serratus juta rupiah).

\section{Pasal 16}

Setiap orang yang dengan sengaja menunjukkan kebencian atau rasa benci kepada orang lain berdasarkan diskriminasi ras dan etnis sebagaimana dimaksud dalam Pasal 4 huruf b angka 1, angka 2, atau angka 3, dipidana dengan pidana penjara paling lama 5 (lima) tahun dan/atau denda paling banyak Rp500.000.000,00 (lima ratus juta rupiah).

\section{Pasal 17}

Setiap orang yang dengan sengaja melakukan perampasan nyawa orang, penganiayaan, pemerkosaan, perbuatan cabul, pencurian dengan kekerasan, atau perampasan kemerdekaan berdasarkan diskriminasi ras dan etnis sebagaimana dimaksud dalam Pasal 4 huruf b angka 4, dipidana sesuai dengan ketentuan peraturan perundang- undangan ditambah dengan 1/3 (sepertiga) dari masing- masing ancaman pidana maksimumnya.

Masing-masing pasal tersebut menjelaskan sanksi yang akan dibebankan kepada pelaku yang diketahui melakukan perbuatan diskriminasi terhadap etnis atau ras tertentu dengan bentuk perbuatan seperti sengaja melakukan pembedaan, pengecualian, pembatasan, atau pemilihan dengan maksud tertentu. Sengaja menunjukkan kebencian atau rasa benci kepada orang lain dengan motif mendiskriminasi rsa atau etnis tertentu. Sengaja melakukan perampasan nyawa orang, penganiayaan, pemerkosaan, perbuatan cabul, pencurian dengan kekerasan, atau perampasan kemerdekaan dengan motif mendiskriminasi rasa tau etnis tertentu.

Berdasarkan Undang-Undang Pemberantasan Tindak Pidana Terorisme pelaku tindak pidana persekusi apabila melanggar ketentuan Pasal 6 UndangUndang Pemberantasan Tindak Pidana Terorisme maka pelaku akan dikenai sanksi sesuai dengan ketentuan pasal tersebut, sanksi yang akan dibebankan kepada pelaku yang diketahui melakukan kekerasan secara meluas yang menimbulkan hilangnya nyawa, merampas kemerdekaan orang lain dengan korban yang bersifat massal atas motif politik, ideoligi, dan gangguan keamanan. 
Pelaku diancam pidana penjara paling singkat 5 tahun dan paling lama 20 tahun, pidana penjara seumur hidup, atau pidana mati.

\section{Kesimpulan}

Persekusi merupakan tindak pidana karena telah memenuhi unsurunsur yang telah ditetapkan dalam peraturan perundang-undangan nasional, yaitu yakni Undang-Undang Nomor 1 Tahun 1946 Tentang Peraturan Hukum Pidana, Undang-Undang Nomor 5 Tahun 2018 tentang Pemberantasan Tindak Pidana Terorisme, Undang-Undang Nomor 40 Tahun 2008 tentang Penghapusan Diskriminasi Ras dan Etnis, dan Undang-Undang Nomor 20 Tahun 2000 tentang Pengadilan Hak Asasi Manusia.

Regulasi terkait dengan persekusi di Indonesia tersebar dalam beberapa peraturan secara terpisah. Jika dalam perbuatannya tidak melibatkan unsur motif maka dapat menggunakan ketentuan Pasal 170, 353, 285, 340 KUHP. Namun apabila motif menjadi pertimbangan dalam pertanggungjawaban pidananya maka undang-undang sectoral seperti Undang-Undang Nomor 5 Tahun 2018 tentang Pemberantasan Tindak Pidana Terorisme, Undang-Undang Nomor 40 Tahun 2008 tentang Penghapusan Diskriminasi Ras dan Etnis, dan UndangUndang Nomor 20 Tahun 2000 tentang Pengadilan Hak Asasi Manusia sebagai dasar pemidanaan pelakunya.

\section{Daftar Bacaan}

\section{Buku}

Andi Hamzah, Delik-Delik Tertentu Didalam KUHP (Sinar Grafika 2017).

Hendry Campbell, Black's Law Dictionary Centennial Sixth Edition (Minn: West Publishing co 1990).

P.A.F Lamintang \& Theo Lamintang, Kejahatan Terhadap Nyawa, Tubuh, E Kesehatan (Sinar Grafika 2010).

Moeljatno, Asas-Asas Hukum Pidana (PT Rineka Cipta 2000). 
Muhammad Hilman: Persekusi Dalam Perspektif...

Moeljatno, KUHP :Kitab Undang-Undang Hukum Pidana (Bumi Aksara 1996).

\section{Perundang-undangan}

Undang-Undang Dasar Negara Republik Indonesia Tahun 1945.

Undang-Undang Nomor 9 Tahun 1998 Tentang Kemerdekaan Menyatakan Pendapat di Muka Umum. (Lembaran Negara Republik Indonesia Tahun 1998 Nomor 181).

Undang-Undang Nomor 39 Tahun 1999 Tentang Hak Asasi Manusia.

Undang-Undang Nomor 26 Tahun 2000 Tentang Pengadilan Hak Asasi Manusia.

Undang-Undang Nomor 48 Tahun 2009 Tentang Kekuasaan Kehakiman.

Undang-Undang Nomor 1 Tahun 1946 Tentang Peraturan Hukum Pidana.

Undang-Undang Nomor 5 Tahun 2018 Tentang Perubahan Atas Undang-Undang Nomor 15 Tahun 2003 Tentang Penetapan Peraturan Pemerintah Pengganti Undang-Undang Nomor 1 Tahun 2002 Tentang Pemberantasan Pidana Terorisme Menjadi Undang- Undang.

Undang-Undang Nomor 40 Tahun 2008 Tentang Penghapusan Diskriminasi Ras dan Etnis.

\section{Laman}

Caecilia Fika, 'Melawan Persekusi Atas Kebebasan Berpendapat' (Kompasiana, 2017)https://www.kompasiana.com/caeciliafica/593bccffbc22bd204122edac/ melawan-persekusi-atas-kebebasan-berpendapat diakses pada 20 Agustus 2019.

Dyah Naelufar 'Indonesia Melawan Bahaya Persekusi' (Liputan 6 news, 2017) https://www.liputan6.com/news/read/2982511/indonesia-melawan-bahayapersekusi diakses pada 20 Agustus 2019.

How to cite: Muhammad Hilman Anfasa Maaroef, 'Persekusi Dalam Perspektif Hukum Positif Indonesia' (2021) Vol. 4 No. 1 Media Iuris. 